\title{
The Relevance of Job Selection of Guidance and Counseling Department Graduates of Lambung Mangkurat University
}

\author{
Ali Rachman, Muhammad Andri Setiawan, Mubarak Al Qarni \\ Department of Guidance and Counseling \\ Universitas Lambung Mangkurat \\ Banjarmasin, Indonesia \\ ali.bk@ulm.ac.id, andri.bk@ulm.ac.id, mubarak.alqarni@ulm.ac.id
}

\begin{abstract}
This research was conducted in order to find out the relevance of job selection of Guidance and Counseling Department graduates of University of Lambung Mangkurat (ULM). The objective of this research is to obtain empirical data of the graduates who have a job in accordance with their major. This research was survey research which used batch 2009-2012 as the population with the number of 182 graduates. The result of survey shows that: (1) $82 \%$ of the graduates job relevant to their degree, (2) $70 \%$ of the graduates got their job three months after graduation, (3) $25 \%$ of the graduates got the job through their connection, and (4) the view of graduates towards guidance and counselor scientific competence was as much as $66 \%$.
\end{abstract}

Keywords - guidance and counseling; graduates; job selection

\section{INTRODUCTION}

University is seen as the institution that is expected to produce qualified human resources [1]. The graduates of alumnus pose as the spearhead of the university's accountability in society. Their existence and activity will always be shadowed by the university's quality. The graduates that well absorbed by the job market, whether they act as entrepreneurs or working with others, become the determiner of whether the existence of the institution (department/major/faculty) will still be maintained or not. In this case, the professional absorption of graduates according to the needs society is reflected in the need for job qualifications tailored to the graduates' undergraduate study.

In this position, the role of study program becomes a strategy for universities to provide graduates who are skillfully specific in certain disciplines, in accordance with the definition of study program itself according to the Regulation of the Minister of Research, Technology and Higher Education of the Republic of Indonesia Number 32 the Year 2016, is defined as a unity of educational and learning activities that have a particular curriculum and learning method in one type of academic education, professional education, and/or vocational education [2].

The interest between the alignments of a graduate education background with his choice of job is crucial to the career direction of the job or known as the relevance of graduate job selection. The research that was conducted by [3] on the graduates of undergraduate degree from the 2013 graduated university, who had got a job in Malang and had been worked for at least three months with the age range of 21-23 years old, showed that the suitability of undergraduate education is seen to support their working skill.

In order to find out the condition of the graduates' job selection after completing their study, the tracking study on them was conducted, so that the tracer study on the graduates was seen as an academic activity that needed and must be implemented by the university in order to be able to obtain feedback from the graduates on the relevance of the educational process that had been undertaken with the ability to increase the living standards of graduates in the society so the university could make improvement based on the corresponding data. The tracer study should at least answer questions about: (1) the graduates' competitiveness that is shown through the waiting time of getting their first job, the success of the graduates in competing in the job selection and salary, (2) the relevance of graduates education is shown through their job profiles and job place), job relevance with the educational background, the benefit of courses they had taken for the graduates, the graduates' suggestions for the improvement of graduates' competency and (3) the graduates' satisfaction, the graduates' competence and suggestions for the improvement of graduates' competency — the correlation between the graduates' extracurricular activities during the study and graduate competitiveness [4].

The disclosure of the relevance of graduates' job selections is essentially related to the development of alumni or graduate tracking, or also known as the tracer study. Tracer study information is used for further development in ensuring educational quality; this activity is expected to gain information on the lack of implementation of the study program and provide the basis of future planning [5]. In order to get the information, the success of professionalism (career, status, income) of the graduates is necessary. Likewise, information on relevant knowledge and skills (the relationship between knowledge and expertise with work needs, the scope of work, professional position) is also required. The graduates are also expected to be able to provide an assessment of the conditions and regulations they learn during their studies after being associated with the world of work they are dealing with. 
[6] stated that tracer study is intended to find empirical evidence from the graduates on the following 8 (eight) objects:

- Characteristics of socio-biography, education, and precollege work.

- Education and learning experience during the course.

- Job search and transition to the world of work.

- Current occupations.

- The relationship between the competencies gained during the study and the demands of the working world.

- Graduates' expectations of the institution.

- Satisfaction of the graduates' institutions/users

- Work value orientation.

The Guidance and Counseling Department of Lambung Mangkurat University (ULM) is one of the study programs in South Kalimantan which produces bachelor of guidance and counseling which will take part in the guidance and counseling career. The guidance counseling and counseling science itself is seen as a systematic, objective, logical, and sustainable and programmed efforts conducted by the counselors or lecturers of the department to facilitate the development of students / counselee to achieve independence in their life (Regulation of the Minister of Education and Culture of Republic of Indonesia No. 111 Year 2014 on Guidance and Counseling on Basic Education and Secondary Education) [7].

Unfortunately, the number of counseling and counseling professionals is still considered inadequate. The fact is the number of counselors or counseling teachers in junior and senior high school, and senior high school is about 52,700 counselors which mean Indonesia still lacks counseling teachers. Of the approximately 52,700 counselors or counseling teachers, while the ideal number is 130,000 counselors, not all of them have counseling education backgrounds. Another problem is that many non-counseling teachers are subjected to be counseling teachers or counselors [8].

Therefore, based on the problems above, the researcher considered it is necessary to conduct research on the relevance of the graduates' job selection of the Guidance and Counseling Department's 2009-2012 graduates in ULM to map how many graduates who have jobs in accordance with the insight of the guidance and counseling.

\section{METHOD}

In this study, the researchers conducted a survey on the relevance of job selection of the graduates of 2009-2012 of the Guidance and Counseling Department of ULM. Ref [9] defines survey research as a study directed at collecting, analyzing and interpreting opinions about certain things in a large population. Survey research typically takes samples from a population and uses a questionnaire as a principal data collection tool in testing the hypothesis [10]. Therefore, survey research has always been associated with samples so that this study is often referred to as a survey sample. The population of this research is the graduates who graduated in 2009-2012, as many as 182 graduates.

This research procedure follows the steps suggested by [9] with a number of adjustments, as follows.

- Formulate the objectives of the study. In this procedure, the purpose of the study is to survey the selection of the graduates' of the 2009-2012 of the Guidance and Counseling Department of ULM job in educational institutions.

- Source voters and target populations. Beginning with identifying graduates from graduate networks across South Kalimantan who were then contacted through various social media such as Facebook, was and line.

- Selection of engineering and instrument development. Data collection used in the research was by the questionnaire in the form of a questionnaire.

- Prepare the filling instructions. In the execution of the survey so that graduates in the filling process can fill in the information that will be required in the instruments prepared online by utilizing the Google Form application.

- Implementation of data retrieval. Conducted from February to March 2017.

- Data processing. Is performed using a simple percentage statistical formula to provide an overview of the relevance of the selection of graduate work.

The tool for collecting data or instruments is arranged in the form of a closed questionnaire. The instrument utilizes the Google Form application to facilitate the collection of instrument data. Google Form is an application in the form of template or worksheet that can be used independently or together for the purpose of obtaining information online. This app works within Google Drive cloud storage alongside other apps like Google Sheet, Google Docs, and more. This template is very easy to understand and use, and is available in many language selections - the requirement to use it only to have a Google account for the form creators. In the data making processing, the questionnaire will use the Google Application Form and Google Sheet later [11].

\section{RESUlTS AND DISCUSSION}

\section{A) The Graduates' Job Selection Relevance}

The graduates of ULM's Guidance and Counseling Department who become guidance and counseling teacher was many as $87 \%$, then the graduates who work at bank and entrepreneurship was $5 \%$ on each, and those who work at the private company was 3\%. This finding shows that the graduates of the Guidance and Counseling Study Program have high relevance to work according to their field. As shown in the figure below. 


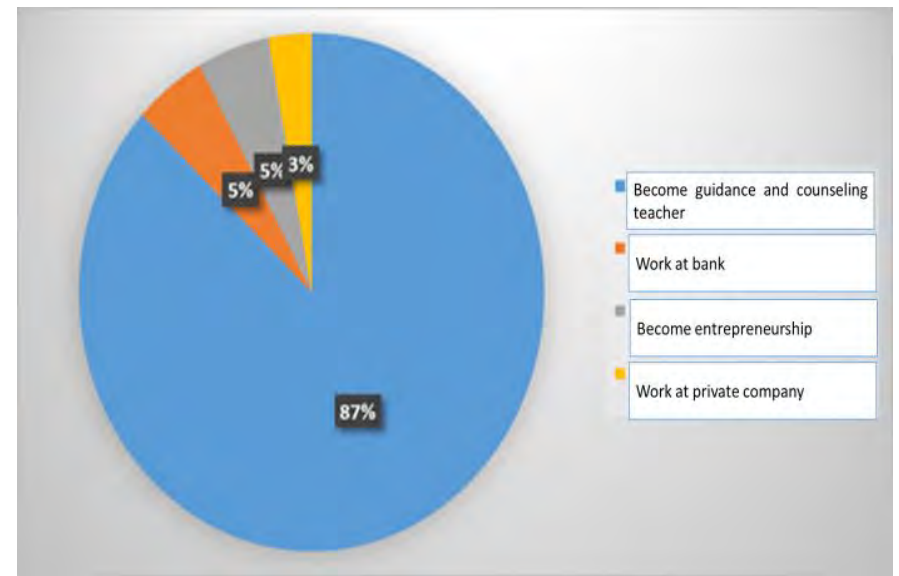

Fig. 1. Job Selection Relevance

This amount is greater than the findings in Rahim \& Puluhulawa's research [12] on the graduates of Guidance and Counseling Department of Gorontalo University which in the range of $77.31 \%$ with details of counseling teachers (Public School) as much as $27.31 \%$ for counseling teachers (NonPublic School). The range of numbers expressed by both of them comes from the sampling on the graduates of the class of 2007-2014, so it does show more varied data.

The other findings that are not less important are the report put forward by [13] which conducted in the Guidance and Counseling Department of Makassar University, which found that $66 \%$ of graduates work in accordance to their degree, obtained from the data source from those who graduated in 2012-2015. So basically it can be stated that the graduates of Guidance and Counseling Study Department are absorbed in the field of work in accordance with their field in an educational institution, which becomes the next interesting drawing is the time span of the graduates in obtaining their job.

\section{B) Time Span in Obtaining Job}

The graduates of the Guidance and Counseling Department of ULM who got a job 3 months after their graduation were as much as $70 \%$, graduates who get a job before graduation were $20 \%$ and $10 \%$ of the graduates got a job more than 3 months. It seems clear that graduates of the Guidance and Counseling Department of ULM get a job not long after completing their studies.

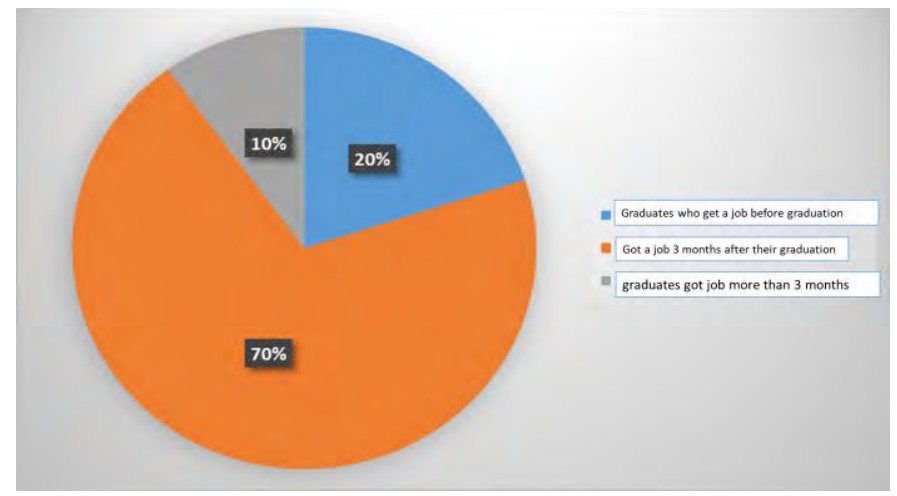

Fig. 2. Time span in Obtaining Job
Based on the data, $70 \%$ of ULM guidance and counseling graduates get a job within 3 months after graduation. This range is still higher than was reported in [12], with waiting periods varying from 2 to 4 months between regencies and cities around Gorontalo, with the percentage of $50 \%$. The time span for this job is not faster than [13] findings which reveal the waiting period for the job very fast because it only waits for 5 months as much as $88 \%$.

\section{C) Information Source of Graduates' Job Obtaining}

The figure below is the description of the information source of the graduates from 2009-2012 classes of the Guidance and Counseling Department of ULM in which it was obtained that the relevant job as a teacher of guidance and counseling in an educational institution.

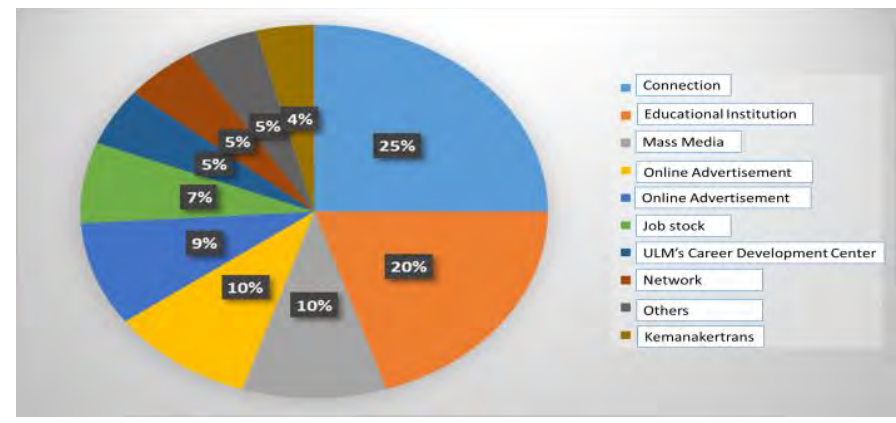

Fig. 3. Information Source of Graduates' Job Obtaining

When the graph is arranged into a table, it is arranged sequentially from the highest percentage to the lowest as follows.

TABLE I. INFORMATION SOURCE OF GRADUATES’ JOB OBTAINING

\begin{tabular}{|l|l|}
\hline \multicolumn{1}{|c|}{ Information Source } & \multicolumn{1}{c|}{$(\%)$} \\
\hline Connection & 25 \\
\hline Educational institution & 20 \\
\hline Mass media & 10 \\
\hline Online advertisement & 10 \\
\hline Job stock & 9 \\
\hline Internship & 7 \\
\hline ULM's Career Development Center & 5 \\
\hline Network & 5 \\
\hline Others & 5 \\
\hline Kemanakertrans & 4 \\
\hline Total & $\mathbf{1 0 0}$ \\
\hline
\end{tabular}

The information source of where the graduates got their job undoubtedly will be the subsequent review, so that can be the way they get the job. In fact, the data obtained indicate that their connection really helps them in getting the job. The connection is certainly the ability to build social interaction based on the spirit of kinship, with a range of $25 \%$. The rest is then followed by the educational institutions and mass media with $20 \%$ and $10 \%$ respectively. One of the interesting ways to get the job is The career development center at ULM, also known as CDC ULM, also play some role for the graduates in getting a job even though the percentage is not that high, only $7 \%$ and $5 \%$. 


\section{D) The Graduates' General Opinion on Their Scientific Competence}

The relevance of graduate job selection also needs to be supported by the graduates' belief in their ability to carry out the work, in this case, the belief of graduates of the Guidance and Counseling Department of ULM on the mastery of scientific knowledge on guidance and counseling. The range of the graduates' mastery on scientific knowledge is considered to be quite good, as many as $66 \%$ and only $13 \%$ of graduates who claim to have excellent scientific mastery, among the percentage of which there are $19 \%$ who claimed they have sufficient mastery. As for those who claim to feel less than enough ranged $2 \%$ and no one who thinks they have no mastery at all.

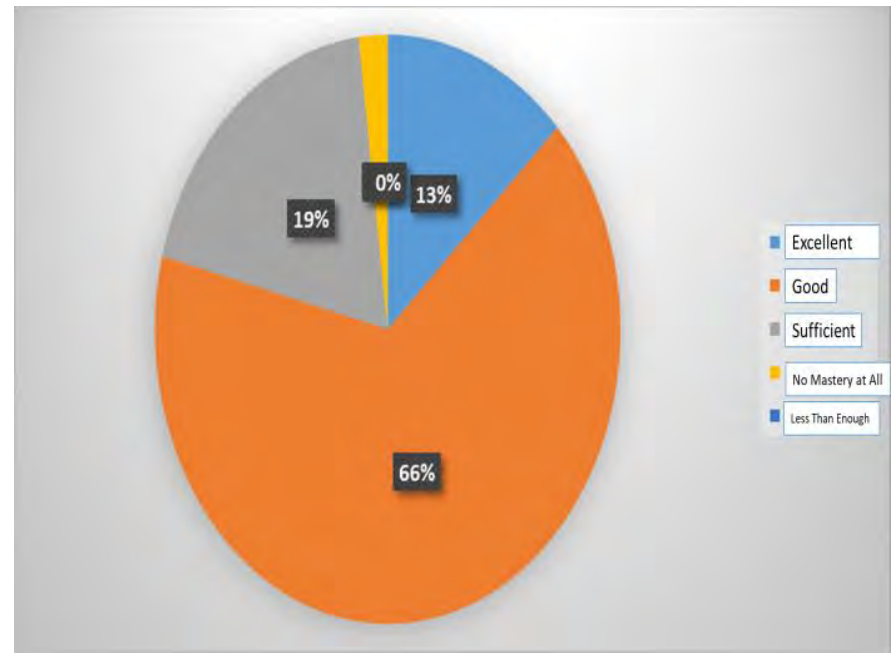

Fig. 4. The graduates' opinion of their scientific competence

\section{CONClusion}

In general, this study concludes that most of the 2009-2012 graduates of the Guidance and Counseling Department of ULM have a job in accordance to the relevance of their scientific competence in college, which guidance and counseling and a job working in accordance with the relevance of scientific guidance and counseling.

\section{REFERENCES}

[1] I. Setyaningsih and M. Abrori, "Analisis Kualitas Lulusan Berdasarkan Tingkat Kepuasan Pengguna Lulusan,” J. Ilm. Tek. Ind., vol. 12, no. 1, pp. 73-82, 2013.

[2] Peraturan Menteri Riset, Teknologi, dan Pendidikan Tinggi Republik Indonesia Nomor 32 Tahun 2016 tentang “Akreditasi Program Studi dan Perguruan Tinggi." 2016.

[3] A. V. Saputra, "Analisis Kesesuaian Pendidikan (S1) dan Pekerjaan yang Didapatkan di Kota Malang (Perilaku Sarjana Fresh Graduate Memperoleh Pekerjaan Pertamanya)," J. Ilm. Mhs. FEB Univ. Brawijaya, vol. 3, no. 1, 2013.

[4] E. Diana and As'ad, "Analisis dan Perancangan Sistem Informasi Tracer Study Berbasis Web,” Mediasisfo, vol. 11, no. 2, pp. 817-829, 2017.

[5] V. K. Bakti, Dairoh, and T. Mustofa, "Sistem Informasi Pelacakan Jejak Alumni (Tracer Study) Berbasis Smart Phone pada Politeknik Harapan Bersama," J. Teknol. Inf. dan Komun., vol. 6, no. 2, p. J. Teknol. Inf. dan Komun., 2015.

[6] K. Suryani and Khairudin, "Tracer Study Online Universitas Bung Hatta," J. Edik Inform. Penelit. Bid. Komput. Sains dan Pendidik. Inform., vol. 2, no. 1, pp. 16-24, 2015.

[7] Peraturan Menteri Pendidikan dan Kebudayaan Republik Indonesia Nomor 111 Tahun 2014 tentang, "Bimbingan dan Konseling pada Pendidikan Dasar dan Pendidikan Menengah.” 2014.

[8] "Prof Mungin: Indonesia Kekurangan Guru BK," DutaNews.net, 2017. [Online]. Available: http://www.dutanews.net/2017/08/07/prof-munginindonesia-kekurangan-guru-bk/. [Accessed: 20-Apr-2018].

[9] N. S. Sukmadinata, Metode Penelitian Pendidikan. Bandung: Remaja Rosdakarya, 2010.

[10] B. Wibawa, Mahdiyah, and J. Afgani, Metode Penelitian Pendidikan. Jakarta: Universitas Terbuka Press, 2014.

[11] J. Slamet, "Otak-atik Google Form Guna Pembuatan Kuesioner Kepuasan Pemustaka," Info Persada Media Inf. Perpust. Univ. Sanata Dharma, vol. 14, no. 1, pp. 21-35, 2016.

[12] M. Rahim and M. Puluhulawa, "Tracer Study Lulusan Program Studi Bimbingan dan Konseling Universitas Negeri Gorontalo,” J. Pendidik. (Teori dan Prakt., vol. 2, no. 2, pp. 121-127, 2017.

[13] M. I. Bakhtiar and S. Latif, "Tracer Study Alumni: Upaya Pengembangan Prodi Bimbingan Konseling Universitas Negeri Makassar," J. Kaji. Bimbing. dan Konseling, vol. 2, no. 1, pp. 32-40, 2017 